\title{
Elements distribution in soil and plants of an old copper slag dump in the Middle Urals, Russia
}

\author{
Ekaterina Zolotova*, Viktor Ryabinin \\ Zavaritsky Institute of Geology and Geochemistry, Ural Branch of Russian Academy of Sciences, \\ 15 Akad. Vonsovsky street, Yekaterinburg, Russia, 620016 \\ *e-mail: afalinakate@gmail.com
}

Received: 17 April 2019 / Accepted: 8 November 2019

\begin{abstract}
The elements concentration in soil and accumulation in plants growing spontaneously on an old copper slag dump were studied. The research object was a landfill site of the Polevskoy copper smelter (Middle Ural, Russia), which is about 200 years old. We investigated composite samples, consisting of soil blocks $(20 \times 20 \mathrm{~cm})$ with growing plants. Samples were selected on a transect of 4-5 $\mathrm{m}$ at equal intervals. The composite sample was divided into slag fractions: stone, gravel, fine soil (particles smaller than $1 \mathrm{~mm}$ ); plant fractions: moss and roots, stems and leaves. The microelement analysis of the samples was carried out at an analytical center of the Institute of Geology and Geochemistry, Ural Branch of RAS. The analyses were performed by inductively coupled plasma mass-spectrometry using Elan-9000 ICP mass-spectrometer. The formation of technogenic soil with a thickness of 10-15 cm on the dump of cast copper slag has begun two hundred years ago. Fine soil constitutes more than one third of the technogenic soil mass and acts as a sorption geochemical barrier. Fine soil accumulates elements mobilized from slag. The concentration of most elements in fine soil is 1-2 orders of magnitude higher than their concentration in slag stone. $\mathrm{Pb}, \mathrm{Cd}, \mathrm{Bi}$ are particularly effectively retained in fine soil: their content is 700-1000 times higher than in slag stone. In the conditions of unlimited supply of elements released from slag, plant reaches the upper threshold of accumulation. The aboveground plant parts compared to litter (roots and moss) have a lower concentration of all elements, but they show the stronger ability to accumulate selenium.
\end{abstract}

Keywords: industrial dump, heavy metals, technogenic soil, anthropogenic ecosystems, elements distribution.

\section{Introduction}

Extraction and processing of minerals leads to soil degradation, natural ecosystems and landscapes destruction, rivers and groundwater pollution, the industrial waste dumps formation (Chibrik et al., 2011; Mensah et al., 2015).

Mining and mineral processing wastes occupy vast areas around the world, disfigures the environment and are pollution sources. Soil and vegetation restoration in manmade landscapes occurs in two variants: reclamation and spontaneous revegetation. Studies of spontaneous revegetation are necessary for the development of man-made territories biological reclamation. The result of success- ful biological reclamation is a sustainable, productive and economically valuable ecosystems (Chibrik et al., 2011; Vymazal \& Sklenicka, 2012)

Spontaneous revegetation of dumps occurs in most cases are extremely slow and with specific features of the soil and plants restoration, which depend on the dumps nature. It should be remembered that plants are able to concentrate certain elements in quantities that are dangerous when included in food chains. Therefore, it is necessary to evaluation the chemical composition of plants growing on dumps (Remon et al., 2005).

Industrial dumps are numerous and diverse. The basis of Russian classification (Tarchevsky, 1970) is the dumps 
origin (mining industry dumps, processing dumps or other), and the remaining features (age, shape, height, mechanical composition of the surface substrate, acidity, the recycling possibility) are explanatory and can be used to characterize all types of dumps.

The features of the soil formation process are quite well considered for the ash dumps of thermal power stations (Zikeli et al., 2002; Uzarowicz \& Zagórski, 2015; Konstantinov et al., 2018) and mining waste (Sourkova et al., 2005; Bragina \& Gerasimova, 2014; Santini \& Banning, 2016; Dvurechensky et al., 2018), but significantly worse for the metallurgy slag dumps. We have found interesting studies of Polish scientists about old pyrometallurgical copper slags (Kierczak et al., 2013). The article considers mineralogical and chemical composition of slags, and the authors attempt to assess the elements migration into soils, river sediments and surface waters.

Vegetation formation is also much more detailed studied for the ash dumps (Makhnev et al., 2002; Glazyrina et al., 2016; Chibrik et al., 2018) and dumps of different deposits (Kupriyanov et al., 2010; Josu et al., 2012; Glazyrina et al., 2016; Lukina et al., 2017), including copper ore (Zheleva et al., 2012; Avensio et al., 2013).

The Ural is a historically developed industrial region, one of the most powerful in Russia. The mining industry has been intensively developing since the beginning of the 20th century. The region is characterized by the presence of large areas of old industrial dumps, where for many decades the natural restoration of soil and vegetation took place. Therefore, the Urals are an excellent research site for research spontaneous revegetation of industrial dumps (Makhnev et al., 2002; Glazyrina et al., 2016; Lukina et al., 2017; Chibrik et al., 2018), and studying the structure and properties of technogenic soils (Makhonina, 2003). However, many questions about the restoration and transformation of vegetation and soil on industrial dumps, especially metallurgical slags, have remained little studied. Single studies about assess the soils and vegetation geochemical transformation in the copper industry dumps (Pasynkova, 1997) are found.

Some studies state that old copper smelting slags are often more dangerous for the environment than modern production wastes, since they were placed uncontrollably, in direct contact with the soil, surface water and groundwater. Old copper smelting slags also contain more potentially toxic elements than modern slags exposed to more technological and advanced smelting processes (Piatak et al., 2004; Vítková et al., 2010; Kierczak et al., 2013).

In connection with the above researches of the chemical composition of technogenic soil and plants in one of the oldest copper slag dumps in the Urals are great interest. The our research purpose was to study of the elements distribution in soil and plants growing spontaneously on the old Polevsky copper smelter dump. Similar studies for this facility have not been conducted.

\section{Materials and methods}

Polevskoy copper smelter is one of the oldest copper smelters and iron smelters in the Urals. It was located on the Dumnaya mountain on the bank of the Polevaya river, a tributary of the Chusovaya river, 52 kilometers southwest of Yekaterinburg (Fig. 1). The coordinates of the study area are $56^{\circ} 26^{\prime} 22^{\prime \prime} \mathrm{N}, 60^{\circ} 11^{\prime} 22^{\prime \prime} \mathrm{E}$. The climate is temper-

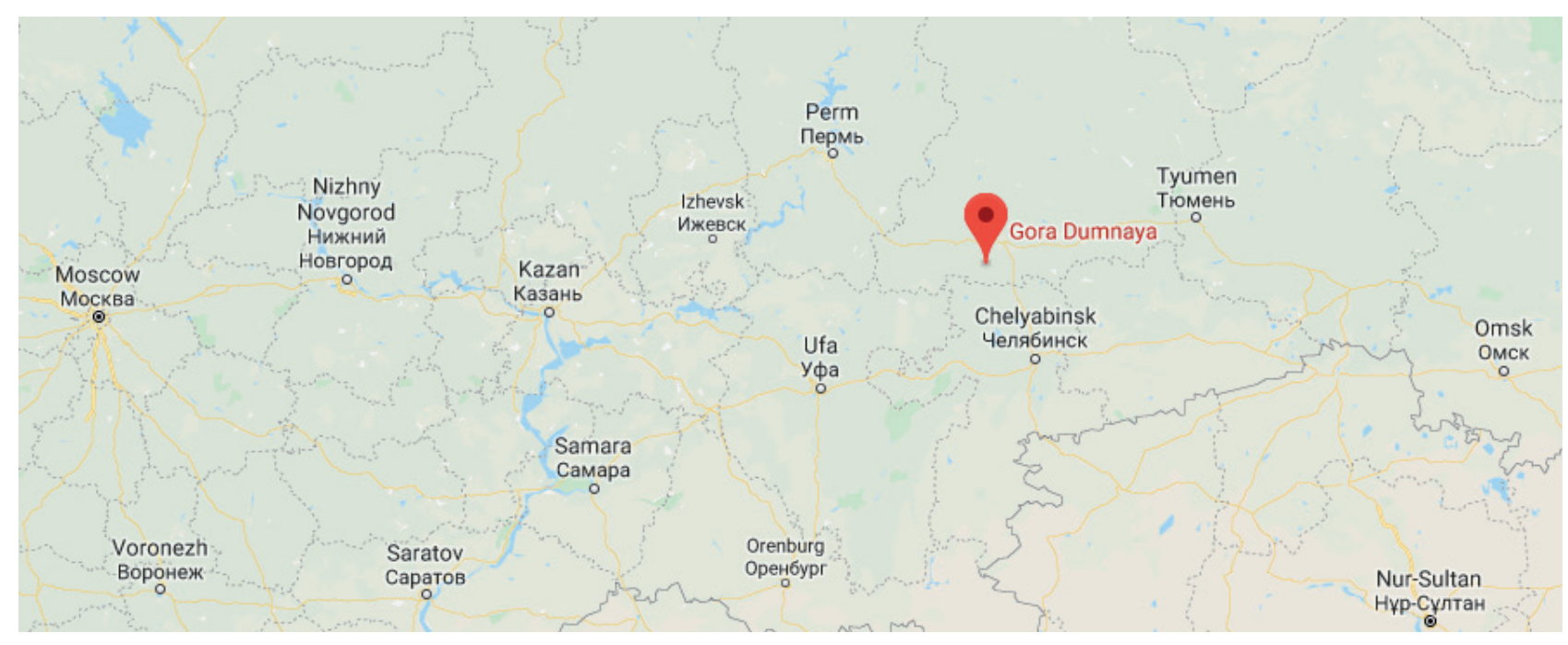

Figure 1. Map of the research area with its location in Russia 
ate continental. Snow cover is established in November and lasts until April. The depth of soil freezing is $1.25 \mathrm{~m}$. The prevailing winds are westerly and southwesterly. The study area belongs to the Middle Ural taiga region (according to the list of forest growing zones and forest regions of the Russian Federation), and to the border of forest growing district identified according to the classification of B.P. Kolesnikov (Kolesnikov et al., 1973): the south taiga forest district of the Trans-Ural hilly foothill province. In the area of the Polevskoy town the primary forests were not preserved, clear cutting was carried out. Derived mixed forests grow.

Polevskoy copper smelter was founded in 1724 and worked until 1930. The oxidation zone of skarn deposit was processed as ore. The technology of producing copper is a mine smelting method. The dump as a result of the activity of Polevskoy copper smelter was formed and has survived to the present day as a steep hill, which is a continuation of the northwestern slope of Dumnaya mountain. A mixed forest with a predominance of birch grows on top of the mountain.

The research object is the Polevskoy copper smelter dump, on which technogenic soil and plants spontaneously growing were formed. The dump is about two hundred years old. According to the classification of V.V. Tarchevsky (1970) the research object refers to bulk medium height (about 10 meters) dumps of the processing industry.

The copper smelting slag of the studied dump is represented by angular black fragments of various sizes with a porous inhomogeneous structure. Oxidation processes are characteristic of the slags; brown iron hydroxides develop along cleavage planes and the upper porous part. The composition of the copper smelting slag includes: manmade silicate glass, pyroxene, magnetite and minerals related to ferrites (Makarov et al., 2018).

We laid the sample plot on a relatively flat terrassoid section of the foot of the northwestern steep slope of the copper smelting dump. The technogenic soil profile was $10-15 \mathrm{~cm}$ and looked like a layer of mostly fine-grained material, which covers coarse-grained crushed stone of the slag. The soil has ensured the development of mixed grass vegetation. The plant roots develop within the dense moss cover and together form a litter.

Soil blocks $(20 \times 20 \mathrm{~cm})$ together with growing plants on a transect of 4-5 m were selected at equal intervals for the our research purpose. The transect was laid along the foot of the dump on a relatively flat section. The main environmental gradients (altitude, humidity, lighting) are the same. The composite sample included four plots $20 \mathrm{x}$ $20 \mathrm{~cm}$. Soil was collected up to the parent rock (slag). The thickness of the soil profile was $10-15 \mathrm{~cm}$. Plant stems with leaves were cut at the root. The material of the composite sample was divided into natural fractions (soil, plants) and according to the size of copper slag fragments, then airdried and weighed (Table 1).

Each fraction of the composite sample was analysed in the chemical laboratory of the Zavaritsky Institute of Geology and Geochemistry of the Ural Branch of the Russian Academy of Sciences. The microelements composition of the samples was determined by inductively coupled plasma mass-spectrometry using Elan-9000 ICP mass-spectrometer. The sample preparation was performed by acid decomposition, followed by autoclave mineralization in the microwave oven. The obtained element concentrations agree with available reference values to a tolerance of about $15 \%$.

\section{Results and discussion}

Man-made ecosystems are very different from natural ones primarily by the lack of a developed soil profile, morphological parameters and properties of the substrate, the structure and productivity of the plant community, and the circulation of matter and energy (Makhonina, 2003; Sibirin et al., 2012).

The investigated technogenic soil of the old Polevskoy copper smelter dump mainly consist of slag particles less than $1 \mathrm{~mm}$. The abundance of fine soil at the dump base may indicate that subsidence of the fine fraction to the

Table 1. Mass of fractions of the composite sample collected at the old copper slag dump (Middle Ural, Russia)

\begin{tabular}{|l|l|c|}
\hline \multicolumn{1}{|c|}{ Fractions of the sample } & \multicolumn{1}{c|}{ Composition of the sample } & Fraction mass \\
\hline Stone & Slag particles over $5 \mathrm{~mm}$ & $32.63 \%$ \\
\hline Gravel & Slag particles $1-5 \mathrm{~mm}$ & $21.98 \%$ \\
\hline Fine soil & Slag particles smaller than $1 \mathrm{~mm}$ & $37.55 \%$ \\
\hline Litter (plant roots and moss) & - & $1.43 \%$ \\
\hline Plant stems and leaves & - & $6.41 \%$ \\
\hline
\end{tabular}


deeper horizons of slag rubble, partial flushing, and accumulation at the foot of the dump slope occurred.

The results of the elemental analysis of the investigated composite sample are presented in Table 2. The chemical composition of the large fraction of the soil sample (slag particles over $5 \mathrm{~mm}$ ) should be taken as the average composition of the soil-forming slag. Mainly all the chemical elements (except Al, V, Cr, Mn, Se, Mn) show signs of accumulation already at the first stage of the stone disintegration - in gravel. The most elements content in gravel is noticeably higher than in stone of slag. The maximum accumulation of all elements occurs in the fine soil (slag particles less than $1 \mathrm{~mm}$ ). We explain the abnormally high content of elements by the fact that the part of the dissolved slag components were washed down along the the slope and sorbed by fine soil from the solu- tion at the foot of the dump slope. The content of deposited $\mathrm{Pb}, \mathrm{Cd}$ and $\mathrm{Bi}$ is especially high, their content in the fine soil is 700-1000 times higher than in stone of slag. The smallest differences in the elements concentrations contained in stone and fine soil of old copper slag dump were found for $\mathrm{Zn}, \mathrm{Sb}, \mathrm{As}, \mathrm{Cu}, \mathrm{Hg}, \mathrm{B}$ and $\mathrm{Ca}$; they concentrations are 100-200 times larger in the fine soil than in the stone.

We used the maximum permissible concentration of total forms of elements (MPC) and concentration coefficient relative to the MPC (Table 3) for ecotoxicological assessment of technogenic soil. Concentration coefficient relative to the MPC is equal to the ratio of the element content in the soil to its maximum permissible concentrations. Maximum permissible concentrations of dangerous chemical elements are regulated in Russia by state documents for

Table 2. The distribution of chemical elements (total, $\mathrm{mg} / \mathrm{kg}$ ) by fractions of the composite sample of the old copper slag dump (Middle Ural, Russia)

\begin{tabular}{|c|c|c|c|c|c|}
\hline Element & Stone & Gravel & Fine soil & Litter (plant roots, moss) & Plant stems, leaves \\
\hline $\mathrm{B}$ & 7.19 & 10.0 & 1,031 & 24.3 & 6.33 \\
\hline $\mathrm{Mg}$ & 8,347 & 12,159 & 351,666 & 9,838 & 674 \\
\hline $\mathrm{Al}$ & 11,271 & 10,619 & 765,271 & 26,779 & 853 \\
\hline $\mathrm{P}$ & 1,840 & 2,215 & 78,628 & 1,691 & 656 \\
\hline $\mathrm{K}$ & 2,167 & 3,661 & 197,295 & 5,060 & 3,632 \\
\hline $\mathrm{Ca}$ & 3,158 & 5,989 & 568,731 & 15,688 & 4,620 \\
\hline V & 116 & 84.1 & 2210 & 44.4 & 1.19 \\
\hline $\mathrm{Cr}$ & 830 & 754 & 11,145 & 187 & 3.33 \\
\hline $\mathrm{Mn}$ & 6,038 & 5,178 & 101,630 & 1,924 & 55.0 \\
\hline Co & 46.4 & 66.3 & 2,282 & 33.6 & 0.984 \\
\hline $\mathrm{Ni}$ & 220 & 507 & 19,035 & 233 & 4.79 \\
\hline $\mathrm{Cu}$ & 201 & 243 & 21,391 & 497 & 18.0 \\
\hline $\mathrm{Zn}$ & 37.6 & 78.0 & 9,137 & 163 & 53.8 \\
\hline As & 9.62 & 14.0 & 999 & 11.6 & 0.555 \\
\hline $\mathrm{Se}$ & 20.0 & - & 984 & 49.9 & 206 \\
\hline Mo & 2.03 & 1.86 & 67.1 & 1.47 & 0.394 \\
\hline $\mathrm{Cd}$ & 0.062 & 0.217 & 56.1 & 1.43 & 0.393 \\
\hline $\mathrm{Sb}$ & 1.08 & 1.79 & 170 & 2.66 & 0.178 \\
\hline $\mathrm{Hg}$ & 1.05 & 1.37 & 118 & 2.14 & 0.396 \\
\hline $\mathrm{Pb}$ & 13.4 & 103 & 14,623 & 140 & 13.0 \\
\hline $\mathrm{Bi}$ & 0.038 & 0.104 & 27.4 & 0.449 & 0.089 \\
\hline
\end{tabular}


environmental objects: for soil this is GN 2.1.7.2041-06 (GN, 2006).

The concentrations of $\mathrm{As}, \mathrm{Mn}, \mathrm{Cu}, \mathrm{Ni}$ exceeded the maximum permissible concentration of elements in all mineral fractions of technogenic soil (stone, gravel, fine soil). The most significant excess concentrations for heavy metals were in the fine soil. Concentrations of $\mathrm{As}, \mathrm{Pb}, \mathrm{Cu}$, Ni were 499, 457, 389, 224 times of the maximum permissible concentration (Table 3), respectively.

Plants absorb almost all chemical elements from the environment. Some elements are necessary for metabolic processes, however, in high concentrations they become toxic for plants, other elements, such as $\mathrm{Pb}, \mathrm{Cd}$, are toxic even in low concentrations (Baker, 1981). The mechanisms of plant resistance are manifested in different directions: some species are able to accumulate high concentrations of heavy metals, but are tolerant to them; others plants seek to reduce their intake by maximizing the use of barrier functions. The first barrier level is the roots, where the largest amount of heavy metals is retained, the next is the stems and leaves, and finally, the last barrier is the organs and parts of plants responsible for reproductive functions (most often seeds and fruits, as well as root and tuber crops) (Ilyin \& Syso, 2001).

For the studied soil litter (mosses and plant roots), most elements (B, Al, K, Ca, Cu, Zn, Se, Cd, Sb, Hg, Pb, Bi) are in concentrations higher than in stone of slag dump, but lower than in fine soil. Probably, the upper threshold of accumulation of these elements in the plant roots and mosses is reached. Despite the abundance of available forms of metals, their further entry into the plants does not occur. Another group of elements ( $, \mathrm{Cr}, \mathrm{Mn}, \mathrm{Co}$, $\mathrm{Mo}$ ) is found in mosses and plant roots in lower concentrations relative to the stone of slag dump, which reflects their lower accumulation threshold. Perhaps the explanation of the identified features in the elements distribution is simplified. The elements migration from soil to plants is a complex and multifactorial process. Analysis of scientific articles showed that a significant positive correlation exists between the metal concentration in soils and some plant species, however for other plant species, for example such as Silene paradoxa, does not exist (Pignattelli et al., 2012).

Aboveground parts of plants have a lower accumulation threshold for all components compared to the litter. However, the content of such chalcophilic elements as Se, $\mathrm{Zn}, \mathrm{Cd}$ and $\mathrm{Bi}$ in plant stems and leaves exceeds that in the stone of the old copper slag dump. The peculiarity of the aboveground parts of plants is the accumulation of selenium.

Potassium and calcium are important elements for vegetation, their concentrations in the plant stems are commensurate with the content of $\mathrm{K}$ and $\mathrm{Ca}$ in the stone of slag dump. However, the concentrations of $\mathrm{Mg}$ and $\mathrm{P}$ in the

Table 3. The ecological assessment of technogenic soil using the element concentration coefficient relative to the maximum permissible concentration

\begin{tabular}{|c|c|c|c|c|}
\hline \multirow{2}{*}{ Element } & \multirow{2}{*}{$\begin{array}{l}\text { Maximum permissible } \\
\text { concentrations, } \mathrm{mg} / \mathrm{kg}\end{array}$} & \multicolumn{3}{|c|}{$\begin{array}{l}\text { Concentration coefficient relative } \\
\text { to the maximum permissible concentration }\end{array}$} \\
\hline & & Stone & Gravel & Fine soil \\
\hline V & 150.0 & 0.770 & 0.560 & 14.7 \\
\hline $\mathrm{Mn}$ & 1,500 & 4.03 & 3.45 & 67.8 \\
\hline $\mathrm{V}+\mathrm{Mn}$ & $100+1,000$ & 5.59 & 4.78 & 94.4 \\
\hline As & 2.0 & 4.81 & 6.99 & 499 \\
\hline $\mathrm{Sb}$ & 4.5 & 0.239 & 0.399 & 37.9 \\
\hline $\mathrm{Hg}$ & 2.1 & 0.501 & 0.652 & 56.5 \\
\hline $\mathrm{Pb}$ & 32.0 & 0.420 & 3.23 & 457 \\
\hline $\mathrm{Pb}+\mathrm{Hg}$ & $20.0+1.0$ & 0.690 & 4.99 & 702 \\
\hline $\mathrm{Cu}^{*}$ & 55 & 3.65 & 4.42 & 389 \\
\hline $\mathrm{Zn*}$ & 100 & 0.376 & 0.780 & 91.4 \\
\hline $\mathrm{Ni}^{*}$ & 85 & 2.59 & 5.97 & 224 \\
\hline
\end{tabular}

* - The approximate values are given in the earlier government document on the regulation of the content of elements in the soil. 
plant stems are significantly less than in slag, despite the recognized high biophilicity.

We calculated the biological absorption coefficients to assess the degree of accumulation of heavy metals by plants. Biological absorption coefficient is the ratio of the content of an element in a plant to the total content of this element in the soil (in our case - fine soil of slag). Visual series of accumulation were compiled. For different parts of the plant sample, an increase in the biological absorption coefficients is as follows:

1. Plant roots and moss:

$\mathrm{Pb}-\mathrm{As}-\mathrm{Ni}-\mathrm{Co}-\mathrm{Sb}-\mathrm{Bi}-\mathrm{Cr}-\mathrm{Zn}-\mathrm{Hg}-\mathrm{Mn}-\mathrm{V}-(\mathrm{Mo}, \mathrm{P})-$ $-\mathrm{Cu}-\mathrm{B}-\mathrm{Cd}-\mathrm{K}-(\mathrm{Ca}, \mathrm{Mg})-\mathrm{Al}-\mathrm{Se}$

The biological absorption coefficients are greatest for selenium (0.051), aluminum (0.035), calcium (0.028) and magnesium (0.028).

2. Plant stems and leaves:

$\mathrm{Ni}-\mathrm{Cr}-\mathrm{Bi}-\mathrm{Co}-(\mathrm{V}, \mathrm{Mn})-\mathrm{As}-\mathrm{Cu}-\mathrm{Pb}-(\mathrm{Sb}, \mathrm{Al})-\mathrm{Mg}-\mathrm{Hg}-$ $-(\mathrm{Mo}, \mathrm{Zn}, \mathrm{B})-\mathrm{Cd}-(\mathrm{Ca}, \mathrm{P})-\mathrm{K}-\mathrm{Se}$

The highest biological absorption coefficients in plant stems and leaves was found for selenium (0.21), potassium (0.018), calcium (0.08) and phosphorus (0.08).

\section{Conclusion}

For two hundred years, the technogenic soil with a capacity of 10-15 cm was formed on the old copper slag dump. Fine soil is more than a third of the mass of technogenic soil and is a sorption geochemical barrier. Fine soil accumulates the elements mobilized from slag. The concentration of most elements in the fine soil by 1-2 orders of magnitude higher than the concentration in the stone of slag. $\mathrm{Pb}, \mathrm{Cd}, \mathrm{Bi}$ are especially effectively retained in the fine soil: their content is 700-1000 times higher than in slag stone. Concentrations of As, Pb, Cu, Ni were 499, 457, 389, 224 times of the maximum permissible concentration.

The plants growing spontaneously on an old copper slag dump has an upper threshold of accumulation in the conditions of a large stock of elements migrating from slag. Litter (plant roots and moss) deposit almost the entire range of elements of copper smelting slag. The biological absorption coefficients (from fine soil) are greatest for selenium (0.051) and aluminum (0.035). The plant stems and leaves in comparison with the litter have a lower concentration of all elements, but they show the stronger ability to accumulate selenium (biological absorption coefficient is 0.21 ).

\section{Acknowledgments}

The study was performed in the framework of the state assignment of the Zavaritsky Institute of Geology and Geo- chemistry, Ural Branch of Russian Academy of Sciences (state registration number AAAA-A18-118052590028-9).

\section{References}

Asensio V., Vega F.A., Andrade M.L. \& Covelo E.F., 2013, Tree vegetation and waste amendments to improve the physical condition of copper mine soils. Chemosphere 90 (2): 603-610. (doi:10.1016/j.chemosphere.2012.08.050).

Baker A.J.M., 1981, Accumulators and excluders strategies in the response of plants to heavy metals. J. Plant Nutr. 3(1/4): 643-654.

Bragina P.S. \& Gerasimova M.I., 2014, Pedogenic processes on mining dumps (a case study of southern Kemerovo oblast). Geography and Natural Resources 35 (1): 35-40.

Chibrik T.S., Lukina N.V., Filimonova E.I. \& Glazyrina M.A., 2011, Ecological foundations and experience of biological reclamation of lands disturbed by industry. Ural University Press, Yekaterinburg, 267 pp.

Chibrik T.S., Lukina N.V., Filimonova E.I., Glazyrina M.A. \& Rakov E.A., 2018, Phytocenosis formation at the Nizhneturinskaya power station ash dumps. Regional Environmental Issues (Problemy regional'noj ehkologii) 6: 27-29. (doi: 10.24411/1728-323X-2019-16027).

Dvurechensky V.G., Sokolov D.A. \& Seredina V.P., 2018, Qualitative assessment of souls in technogenic landscapesof Gorlovskiy anthracitous deposit. Bulletin of NSAU (Novosibirsk State Agrarian University) 3(48): 53-61. (doi:10.31677/2072-6724-2018-48-353-61).

Glazyrina M.A., Filimonova E.I., Lukina N.V. \& Chibrik T.S., 2016, Study of plant populations on industrial dumps. Ural University Press, Yekaterinburg, 228 pp.

GN 2.1.7.2041-06, 2006, Predel'no dopustimye koncentracii (PDK) himicheskih veshchestv v pochve [Maximum permissible concentration (MPC) of chemicals in the soil], 6 pp.

Ilyin V.B. \& Syso A.I., 2001, Trace elements and heavy metals in soils and plants of the Novosibirsk region. Publisher SB RAS, Novosibirsk, 231 pp.

Josu G., Alday J.G., Marrs R.H. \& Martínez-Ruiz C., 2012, Soil and vegetation development during early succession on restored coal wastes: a six-year permanent plot study. Plant Soil 353: 305. (doi:10.1007/s11104-0111033-2).

Kierczak J., Potysz A., Pietranik A., Tyszka R., Modelska M., Néel C., Ettler V. \& Mihaljevič M., 2013, Environmental impact of the historical $\mathrm{Cu}$ smelting in the Rudawy Janowickie Mountains (south-western Poland). Journal of Geochemical Exploration 124: 183-194. 
Kolesnikov B.P., Zubareva R.S., Smolonogov E.P., 1973, Forest vegetation conditions and forest types of the Sverdlovsk region. UNTS of Academy of Science of the USSR, Sverdlovsk, $176 \mathrm{pp}$.

Konstantinov A.O., Novoselov A.A. \& Loiko S.V., 2018, Special features of soil development within overgrowing fly ash deposit sites of the solid fuel power plant. Tomsk State University Journal of Biology 43: 6-24. (doi: 10.17223/19988591/43/1).

Kupriyanov A.N., Manakov Yu.A. \& Barannik L.P., 2010, Restoration of ecosystems in the dumps of the mining industry of Kuzbass. Academic Publishing House “Geo", Novosibirsk, 160 pp.

Lukina N.V., Glazyrin M.A., Filimonova E.I., Chibrik T.S \& Shapovalova K.I., 2017, Formation the vegetation on Bazhenovskiy deposit of chrysotile-asbestos. Izvestia of Samara Scientific Center of the Russian Academy of Sciences 19(2/2): 294-299.

Makarov A.B., Khasanova G.G., Koinov S.A., 2018. Mineralogical and geochemical features starreally toxins Polevsky copper-smelting plant (the Middle Urals, Sverdlovsk region). Problemy mineralogii, petrografii I metallogenii. Nauchnye chteniya pamyati P.N. Chirvinskogo [Problems of mineralogy, petrography and metallogeny. Scientific readings of memory P.N. Chirvinsky] 21: 430-435.

Makhonina G.I., 2003, Ecological aspects of soil formation in the technogenic ecosystems of the Urals. Ural University Publishing House, Yekaterinburg, 356 pp.

Makhnev A.K., Chibrik T.S., Trubina M.R., Lukina N.V., Gebel' N.E., Terin A.A., Elovikov Yu.I., Toporkov N.V., 2002, Ekologicheskie osnovy i metody biologicheskoy rekul'tivatsii zolootvalov teplovykh elektrostantsiy na Urale [Ecological bases and methods of biological recultivation of ash dumps of thermal power stations in the Urals]. Ural Branch of the Russian Academy of Sciences Publishing, Yekaterinburg, 356 pp.

Mensah A.K., Mahiri I.O., Owusu O., Mireku O.D., Wireko I. \& Kissi E.A., 2015, Environmental Impacts of Mining: A Study of Mining Communities in Ghana. Applied Ecology and Environmental Sciences 3(3): 81-94. (doi:10.12691/aees-3-3-3).

Pasynkova M.V., 1997, Heavy metals in the soil - plant system on the dumps of the copper industry. Ecological Studies in the Urals. Ural State University, Yekaterinburg: 120-133.

Piatak N.M., Seal II R.R. \& Hammarstrom J.M., 2004, Mineralogical and geochemical controls on the release of trace elements from slag produced by base- and precious-metal smelting at abandoned mine sites. Applied Geochemistry 19: 1039-1064.
Pignattelli S., Colzi I., Buccianti A., Cecchi L., Arnetoli M., Monnanni R., R.Gabbrielli R., Gonnelli C., 2012, Exploring element accumulation patterns of a metal excluder plant naturally colonizing a highly contaminated soil. Journal of Hazardous Materials 227-228: 362-369. (doi:10.1016/j.jhazmat.2012.05.075).

Remon E., Bouchardon J.-L., Cornier B., Guy B., Leclerc J.-C. \& Faure O., 2005, Soil characteristics, heavy metal availability and vegetation recovery at a former metallurgical landfill: Implications in risk assessment and site restoration. Environmental Pollution 137(2): 316-323. (doi:10.1016/j.envpol.2005.01.012).

Santini T.C. \& Banning N.C., 2016, Alkaline tailings as novel soil forming substrates: Reframing perspectives on mining and refining wastes. Hydrometallurgy 164: 38-47. (doi:10.1016/j.hydromet.2016.04.011).

Sibirina L.A., Polokhin O.V. \& Zhabyko E.V., 2012, Initial stages of the formation of plant cover on industrycaused ecotopes of the Primorsky territory. Izvestia of Samara Scientific Center of the Russian Academy of Sciences 14(1/6): 1539-1542.

Sourkova M., Frouz J. \& Santruckova H., 2005, Accumulation of carbon, nitrogen and phosphorus during soil formation on alder spoil heaps after brown-coal mining, near Sokolov (Czech Republic). Geoderma 124: 203-214.

Tarchevsky V.V., 1970, Classification of industrial dumps, [in:] Vegetation and industrial pollution: The Nature Conservation in the Urals. Sverdlovsk: 84-89.

Uzarowicz Ł. \& Zagórski Z., 2015, Mineralogy and chemical composition of technogenic soils (Technosols) developed from fly ash and bottom ash from selected thermal power stations in Poland. Soil Science Annual 66(2): 82-91.

Vítková M., Ettler V., Johan Z., Kříbek B., Šebek O. \& Mihaljevič M., 2010, Primary and secondary phases in copper-cobalt smelting slags from the Copperbelt Province, Zambia. Mineralogical Magazine 74: 581-600.

Vymazal J. \& Sklenicka P., 2012, Restoration of areas affected by mining. Ecological Engineering 43: 1-4.

Zheleva E.I., Bozhinova P.M. \& Venelinov M.A., 2012, Phytocenological characteristics of bulk of rock overburdened dumps of mine "Ellatzite". Biological recultivation and monitoring of disturbed industrial lands. Ural University Press, Yekaterinburg: 103-112.

Zikeli S., Jahn R. \& Kastler M., 2002, Initial soil development in lignite ash landfills and settling ponds in Saxony-Anhalt, Germany. Journal of Soil Science and Plant Nutrition 165: 530-536. (doi:10.1016/j.hydromet.2016.04.011). 